\title{
The Effect of Induced Diabetes Mellitus on the Cerebellar Cortex of Adult Male Rat and the Possible Protective Role of Oxymatrine: A Histological, Immunohistochemical and Biochemical Study
}

Amany Mohamed Shalaby ( $\sim$ amanyshalaby84@gmail.com )

Tanta University Faculty of Medicine https://orcid.org/0000-0002-5233-1990

Adel Mohamed Aboregela

Zagazig University Faculty of Human Medicine

Mohamed Ali Alabiad

Zagazig University Faculty of Human Medicine

Mona Tayssir Sadek

Tanta University Faculty of Medicine

\section{Research Article}

Keywords: Cerebellum, Diabetes, Oxymatrine, GFAP, Synaptophysin

Posted Date: March 19th, 2021

DOI: https://doi.org/10.21203/rs.3.rs-300672/v1

License: (ㅇ) (i) This work is licensed under a Creative Commons Attribution 4.0 International License. Read Full License 


\section{Abstract}

Diabetes mellitus (DM) represents a widespread metabolic disease with a well-known neurotoxicity in both central and peripheral nervous systems. Oxymatrine is a traditional Chinese herbal medicine that has various pharmacological activities including; antioxidant, anti-apoptotic and anti-inflammatory potentials. The present work aimed to study the impact of diabetes mellitus on the cerebellar cortex of adult male albino rat and to evaluate the potential protective role of oxymatrine using different histological methods. Fifty-five adult male rats were randomly divided into three groups: group I served as control, group II was given oxymatrine ( $80 \mathrm{mg} / \mathrm{kg} /$ day) orally for 8 weeks and group III was given a single dose of streptozotocin $(50 \mathrm{mg} / \mathrm{kg})$ intaperitoneally to induce diabetes. Then diabetic rats were subdivided into two subgroups: subgroup Illa that received no additional treatment and subgroup IIIb that received oxymatrine similar to group II. The diabetic group revealed numerous changes in the Purkinje cell layer in the form of multilayer arrangement of Purkinje cells, shrunken cells with deeply stained nuclei as well as focal loss of the Purkinje cells. A significant increment in GFAP and synaptophysin expression was reported. Transmission electron microscopy showed irregularity and splitting of myelin sheaths in the molecular layer, dark shrunken Purkinje cells with ill-defined nuclei, dilated Golgi saccules and dense granule cells with irregular nuclear outlines in the granular layer. In contrast, these changes were less evident in diabetic rats that received oxymatrine. In conclusion, Oxymatrine could protect the cerebellar cortex against changes induced by DM.

\section{Introduction}

Diabetes mellitus (DM) is a common metabolic disease caused by deficiency in insulin secretion and/or insulin resistance (Ozougwu et al., 2013). Insulin deficiency usually results in a condition of chronic hyperglycemia with alterations in carbohydrates, lipids and proteins metabolism (Mohammadi et al., 2011). Uncontrolled diabetes usually results in various complications such as heart diseases, gastrointestinal disorders, eye disease, neuropathy and nephropathy together with increased mortality (Patel and Macerollo, 2010). Neuropathies of autonomic and peripheral nervous systems are considered the most common complication of DM. Besides these neuropathies, diabetes is also correlated with development of end-organ damage in the central nervous system (Brands et al., 2004). This condition is termed 'diabetic encephalopathy', which is accompanied by memory dysfunction and electrophysiological alterations (Allen et al., 2004). Structural, neurochemical and degenerative changes in the brain are also associated with these functional abnormalities (Hernández-Fonseca et al., 2009). In addition, it was reported that insulin signaling in the brain not only controls food consumption and glucose homeostasis but is also involved in both survival and maintenance of the cognitive activity of the general neural network, thus, the changes in serum insulin levels secondary to diabetes mellitus can directly cause brain injury and neurodegenerative diseases (Duarte et al., 2012).

Cerebellum is one of the particular brain regions that has a high expression of insulin receptors in its cortex (Kleinridders et al., 2014). Besides its motor functions, which include balance maintenance and movement coordination, cerebellum is also concerned with learning and memory (Tedesco et al., 2011). Imaging analysis for the brain white matter in diabetic patients showed a decrease in the connections within the cerebellum and cerebro-cerebellar pathways (Fang et al., 2017). The apoptotic activity has been reported to be increased in the cerebellum of diabetic rats (Hernández-Fonseca et al., 2009). Moreover, Hami and co-workers revealed that maternal diabetes affected the synaptogenesis of the developing cerebellum in the offspring (Hami et al., 2016). Streptozotocin (STZ)-induced diabetes mellitus in rats is a well-established model for induction of DM owing to its harmful impact on the pancreatic $\beta$ cells. This model is employed in the current research for evaluating the histological changes in the cerebellum caused by DM (Hashish, 2015).

Traditional Chinese remedies are commonly employed in both prophylaxis and management of refractory health problems due to their available resources, therapeutic outcomes on various targets, less adverse effects and reduced cost care (Xu et al., 2014). Oxymatrine is the major quinolizidine alkaloid extracted from the root of a traditional Chinese herb; Sophora flvescens (Funaya and Haginaka, 2012). Oxymatrine has extensive pharmacological activities, including anti-viral (Wang et al., 2011), anti-oxidant (Zhou et al., 2016), anti-tumor (Wu et al., 2015) and anti-inflammatory effects (Dai et al., 2018). Also, it has been shown to suppress the neuroinflammatory reactions and to delay the development of neurodegenerative diseases (Ding et al., 2016). Additionally, oxymatrine was reported to exert neuroprotective effects on cerebral ischemia/reperfusion injury in animal models (Cui et al., 2011). Previous studies showed that administration of oxymatrine significantly reduced the level of blood glucose in mice fed with high fructose diet (Zeng et al., 2012) and improved the insulin sensitivity in diabetic rats, thus, it was predicted that oxymatrine may have a beneficial impact on diabetes mellitus (Zuo et al., 2019). Hence, this work was performed to investigate the potential role of oxymatrine against cerebellar cortex injury caused by DM in rats using different histological methods. 


\section{Materials And Methods}

\section{Experimental animals}

This research was performed on 55 adult male Wistar albino rats. Their average weight was 180 to $200 \mathrm{~g}$. The animals were acclimatized for seven days before the experimental work began. The animal procedures were approved by the Faculty of Medicine's local Institutional Animal Ethics Committee, Tanta University, Egypt (Approval number: 34265/11/20).

\section{Chemicals}

Streptozotocin and oxymatrine (with a purity >98\%) were bought from Sigma-Aldrich Saint Louis, Missouri, USA.

\section{Experimental design}

The rats were randomly divided into the following groups:

Group I (Control group): included 15 rats that were further subdivided into three subgroups:

Subgroup (la): received no treatment during the experiment.

Subgroup (lb): received $1 \mathrm{ml}$ of normal saline $(0.9 \% \mathrm{NaCl})$, the diluting vehicle for oxymatrine.

Subgroup (Ic): received a single intraperitoneal injection of $0.2 \mathrm{ml}$ of $0.1 \mathrm{M}$ sodium citrate, the diluting vehicle for streptozotocin.

Group II (Oxymatrine group): included 10 rats that received oxymatrine dissolved in normal saline at a dose $80 \mathrm{mg} / \mathrm{kg} / \mathrm{day}$ by oral gavage for 8 weeks (Shi et al., 2013).

Group III (The streptozotocin-induced diabetic group): included 30 rats that were subjected to a single intraperitoneal injection of $50 \mathrm{mg} / \mathrm{kg} \mathrm{STZ}$ freshly dissolved in cold 0.1M sodium citrate buffer, pH 4.5 (Hashish, 2015). 72 hours after STZ injection, diabetes mellitus induction was confirmed by evaluation of the glucose levels in blood samples obtained from the tail vein using the ACCUCHEK glucose meter (Roche Diagnostic Corporation, Indianapolis, IN). Only animals with blood glucose level of ( $\geq 250 \mathrm{mg} / \mathrm{dl})$ were considered diabetic (Eltahawy et al., 2017). In this research, only 22 rats were proved to develop DM after STZ injection and were further subdivided into 2 experimental subgroups:

Subgroup Illa (Induced diabetic group): included 11 rats that received no additional treatment.

Subgroup Illb (Induced diabetic-oxymatrine group): included 11 rats that received oxymatrine at a dose, route and duration similar to that of group II.

24 hours after the last dose of oxymatrine, the glucose levels in blood samples obtained from the tail vein were measured and the rats were anesthetized by ketamine (60 mg/kg i.p) (Hashish, 2015). The heads were then dissected to collect the cerebellar specimens. Parts of the cerebellum were used for the biochemical analysis of othe xidative stress and the other part was split into two pieces. One was processed for light microscopic study and the other for electron microscopic study.

\section{Assessment of Oxidative Stress}

Tissue malondialdehyde (MDA) levels, glutathione peroxidase (GP-x), and superoxide dismutase (SOD) were determined according to the previous methods described by (Uchiyama and Mihara, 1978), (Paglia and Valentine, 1967), (Marklund and Marklund, 1974), respectively .

\section{Light microscopic studies}

The cerebellar specimens from each animal were fixed in $10 \%$ buffered formalin solution for 24 hours, then dehydrated in graded alcohol and embedded in paraffin. Serial sections of $5 \mu \mathrm{m}$ thickness were cut and the following techniques were applied:

- Hematoxylin and eosin (H\&E) stain: to illustrate the general histological features of the cerebellum (Gamble and M, 2008). 
- Immunohistochemical stains using streptavidin-biotin-peroxidase technique according to (Shalaby and Bahey, 2018). The sections were incubated for 2 hours with the following:

- Diluted primary antibody against glial fibrillary acidic protein (GFAP); a mouse monoclonal antibody (SC-58766, Santa Cruz Biotechnology, INC).

- Monoclonal antibody against synaptophysin (SC- 17750, Santa Cruz Biotechnology, INC).

\section{Electron microscopic study}

The processing of the cerebellar specimens for examination by transmission electron microscope was carried out according to (Woods and Stirling, 2008). Briefly, very small parts of the cerebellar tissue $\left(1 \mathrm{~mm}^{3}\right)$ were fixed in $2.5 \%$ phosphate-buffered glutaraldehyde, post-fixed in 1\% phosphate buffer osmium tetroxide, dehydrated in ascending grades of alcohol then immersed in propylene oxide and finally embedded in epoxy resin mixture. Ultrathin sections (80-100 nm thick) were cut, contrasted with uranyl acetate and lead citrate and examined by JEOL-JEM-100 transmission electron microscope (Japan) in Electron Microscopic unit, Faculty of Medicine, Tanta University, Egypt.

\section{Morphometric study}

Leica Qwin 500 image analyzer computer system was employed to measure:

- Mean number of Purkinje cells /mm length of the cerebellar lobules in H\&E-stained sections at a magnification of $x$

- Mean area percentage and mean optical density of GFAP expression in DAB-stained sections at a magnification of $x$

- Mean optical density of synaptophysin expression in DAB-stained sections at a magnification of $x$

Ten non-overlapping random fields per slide from each rat in all studied groups were used in these measurement.

\section{Statistical analysis}

One-way analysis of variance and Tukey's procedure were employed to compare between the different groups. The values were expressed as mean \pm SD. Differences were considered significant if the probability value ( $p$ value) was less than 0.05 (DawsonSaunders and Trapp, 2001).

\section{Results}

Regarding rats' mortality during the experiment, two rats from the induced diabetic group (subgroup IIla) and only one rat from the induced diabetic-oxymatrine group (subgroup IIIb) died. Regarding the biochemical, histological and immunohistochemical findings, all subgroups (la, lb, and Ic) of the control group, they exhibited no statistical differences, thus they were collectively referred to as the control group. Meanwhile, there was non-significant statistical differences between the control group (group I) and oxymatrine group (group II).

\section{Biochemical results}

The induced diabetic group (subgroup IIla) exhibited a significant increment in the blood glucose level (323.88 $\pm 20.68 \mathrm{mg} / \mathrm{dl}) \mathrm{when}$ compared with the control one $(104.43 \pm 9.59 \mathrm{mg} / \mathrm{dl})$. Administration of oxymatrine to the diabetic rats significantly minimized the blood glucose increase but it failed to normalize the level of blood glucose, thus it showed a significant increment $(265.98 \pm 62.84$ $\mathrm{mg} / \mathrm{dl}$ ) when compared with the control group (Table 1).

\section{Oxidative stress assessment}

A significant increment in the MDA level $(91.59 \pm 4.88 \mathrm{nmol} / \mathrm{g})$ and a significant decrement in the levels of GP-x $(0.41 \pm 0.03 \mathrm{U} / \mathrm{mg})$ and $\operatorname{SOD}(25.19 \pm 3.24 \mathrm{U} / \mathrm{g})$ were detected in the induced diabetic group (subgroup IIla) when compared to the control one $(70.09 \pm 2.29$ $\mathrm{nmol} / \mathrm{g}, 0.68 \pm 0.03 \mathrm{U} / \mathrm{mg}, 39.61 \pm 3.01 \mathrm{U} / \mathrm{g}$, respectively). Administration of oxymatrine to the diabetic rats in subgroup Illb succeeded in normalizing the oxidative stress parameters and thus it revealed no significant difference $(70.53 \pm 3.60 \mathrm{nmol} / \mathrm{g}, 0.66 \pm 0.07 \mathrm{U} / \mathrm{mg}$, $36.79 \pm 5.35 \mathrm{U} / \mathrm{g}$, respectively) when compared with the control group (Table 1).

\section{Histological results}




\section{H\&E-stained sections}

The cerebellar sections of the control group displayed the normal histological architecture of the rat cerebellar cortex. It was formed of three layers; the molecular layer, the Purkinje cell layer that consisted of one row of large pear-shaped cells with vesicular nuclei and prominent nucleoli and the granular cell layer that demonstrated densely packed rounded cells having darkly stained nuclei with cerebellar islands in-between (Fig. 1A). Cerebellar sections from the induced diabetic group (subgroup Illa) displayed numerous changes that were more obvious in the Purkinje cell layer. Purkinje cells were arranged in many layers with many neuroglial cells inbetween (Fig. 1B). Most of them were irregular in shape with shrunken deeply stained nuclei (Fig. 1C). Others showed eosinophilic homogenization of their cytoplasm and faint nuclei (Fig. 1D). Vacuolation of the Purkinje cell layer (Figs. 1B,C\&D), focal disappearance of Purkinje cells together with presence of cell remnants were also detected (Fig. 1E). As regards the molecular layer, it showed vacuolations in some sections (Fig. 1C). The granular cell layer showed presence of vacuoles (Fig. 1B). Some granule appeared darkly stained (Fig. 1E). Examination of cerebellar sections obtained from the induced diabetic-oxymatrine group (subgroup IIIb) revealed preservation of the normal cerebellar architecture as regards its three layers except for presence of few darkly stained shrunken Purkinje cells (Fig. 1F).

Statistical analysis of the mean number of Purkinje neurons $/ \mathrm{mm}$ of the cerebellar lobules showed a significant decrement $(9.05 \pm 1.53)$ in the induced diabetic group (subgroup Illa) compared with the control group (21.12 \pm 1.51$)$. Whereas the induced diabetic-oxymatrine group (subgroup IIIb) revealed a non-significant change (19.50 \pm 1.49 ) when compared to the control group (Table 2).

\section{Immunohistochemical results}

Examination of GFAP-immunostained cerebellar cortex sections of the control group displayed mild GFAP expression in the cytoplasm of the cell body and processes of the astrocytes of all cortical layers (Fig. 2A). Whereas the GFAP expression in the astrocytes was intense in all cortical layers of the induced diabetic group (subgroup IIla) (Fig. 2B). While the induced diabeticoxymatrine group (subgroup IIlb) revealed moderate GFAP expression in the astrocytes of all cortical layers (Fig. 2C). Statistical analysis of the mean area percentage and the mean optical density of GFAP expression in the cerebellar cortex showed a significant increase $(30.02 \pm 0.62,27.20 \pm 3.51$ respectively) in the induced diabetic group (subgroup IIla) when compared with the control one $(9.70 \pm 0.79,11.44 \pm 1.57$ respectively). As regards the induced diabetic-oxymatrine group (subgroup IIIb), there was a non-significant change in the mean area percentage and the mean optical density of its GFAP expression $(10.15 \pm 0.43,8.96 \pm 1.27$ respectively) when compared to the control group (Table 2).

Examination of synaptophysin-immunostained sections of the cerebellar cortex of the control group showed weak expression of synaptophysin in the molecular and granular layers (Fig. 3A). While the cerebellar cortex sections of the induced diabetic group (subgroup IIla) exhibited strong expression of synaptophysin in both molecular and granular layers (Fig. 3B). As regards the induced diabetic-oxymatrine group (subgroup IIlb), it showed moderate synaptophysin expression in molecular and granular layers (Fig. 3C). Statistical analysis of the mean optical density of synaptophysin immunoexpression revealed a significant increase (33.85 \pm 0.73$)$ in the induced diabetic group (subgroup IIla) in comparison with the control group (12.53 \pm 0.80 ). Meanwhile, the induced diabeticoxymatrine group (subgroup IIlb) showed a significant increment (15.43 \pm 0.58 ) in comparison with the control group (Table 2).

\section{Transmission electron microscopic results}

Examination of the cerebellar cortex from the control group revealed regular arrangement of myelin sheaths in the molecular layer (Fig. 4A). The perikaryons of Purkinje cells in the Purkinje cell layer contained large euchromatic nuclei with prominent nucleoli, mitochondria and rER (Fig. 4B). The granular layer displayed two cell types; granule cells with heterochromatic nuclei surrounded by thin rim of cytoplasm and Golgi cells (Fig. 4C). On the other hand, sections from the induced diabetic group (subgroup Illa) showed irregularity and splitting of the myelin sheaths in the molecular layer (Fig. 5A). Moreover, many Purkinje cells were shrunken and dark with ill-defined nuclei and dilated Golgi saccules. Vacuolation of the surrounding neuropil was also detected (Fig. 5B). Other Purkinje cells had irregular nuclei with dilated perinuclear cisternae, dilated rER and vacuolated cytoplasm (Fig. 5C). Cells of the granular layer appeared dark with irregular nuclear outlines and vacuolated cytoplasm. Some cells revealed pyknotic nuclei (Fig. 5D). As regards the induced diabetic-oxymatrine group (subgroup IIlb), it displayed partial preservation of the cerebellar cortex structure. Most of the nerve fibers in the molecular layer showed regular arrangement of the myelin sheaths. However, few nerve fibers revealed irregularity of their myelin sheaths (Fig. 6A). Most of the Purkinje cells appeared normal, however, few cells showed indentation of the nuclear 
membranes (Fig. 6B) and others had dark cytoplasm (Fig. 6C). Also, most of the granule cells were normal, whereas some cells revealed rarefaction of their cytoplasm (Fig. 6D).

\section{Discussion}

Diabetes mellitus represents a widespread metabolic disease with well-known side effects. Prolonged hyperglycemia in DM usually causes neurotoxicity in peripheral and central nervous systems (Hashish, 2015). In our research, we evaluated the role of oxymatrine in alleviating cerebellar cortex changes induced by DM in rats. The current study revealed that DM induced structural changes in rats' cerebellar cortex as evidenced by light and electron microscopic results. These changes were more obvious in the Purkinje cell layer. The Purkinje cells were arranged in many layers. Most of them were shrunken with deeply stained nuclei. Others showed eosinophilic homogenization of their cytoplasm with fainting of the nuclei. Moreover, focal disappearance of Purkinje cells was also detected. Results of the current work came in agreement with (Sherif, 2017) and (Hussein, 2015) in their studies on the cerebellum of diabetic rats.

The hyperglycemia developed in DM induces oxidative stress which accounts for generation of reactive oxygen species (ROS) and lipid peroxidation. This usually leads to oxidation of proteins, damage of DNA together with peroxidation of the lipids present within the plasma membranes and causes an increase in neuronal cells death (Zhao et al., 2013). The condition of oxidative stress developed in diabetes mellitus also leads to glucose auto-oxidation, a decrease of tissues' glutathione concentration and depletion of the antioxidant enzyme activities with subsequent increase in the sensitivity of the brain tissue to oxidative damage (Altinzo et al., 2014). This was in agreement with the significant increment in the MDA level and the significant decrement in the levels of GP-x and SOD that were reported in our research.

The Purkinje cells are considered the largest and the most obvious neuron in the cerebellum (Huang et al., 2017). They are concerned with learning and motor function coordination, therefore, their damage causes motor disorders (Nagayach et al., 2014). In the present research, a significant decrement in the Purkinje cells' number was detected in the induced diabetic group (group Illa). This result came hand in hand with the results of previous researches by (Razi et al., 2015) and (Bak et al., 2015) who reported a decrement in the number of Purkinje cells in their study on diabetic rats. Such decrease in number could be attributed to either programmed cell death or decreased neurogenesis in the CNS (Hernández-Fonseca et al., 2009) or acidosis of the tissues (DeBoer et al., 2005) that all occur due to hyperglycemia. Meanwhile, exposure of Purkinje cells to the oxidative stress caused by DM causes their damage secondary to glycation and intracellular accumulation of a-synuclein; a neuronal protein associated with synaptic plasticity, neurotransmitters release, neurons differentiation and also neuronal viability regulation (Liu et al., 2009; Solmaz et al., 2017).

The multilayer arrangement of the Purkinje cells reported in this research could be attributed to focal crowding of the cells as a part of an adaptive mechanism of the Purkinje cells in order to re-establish connections with each other in order to perform their functions (El-Dien et al., 2010). The vacuolations that was detected in the three layers of the cerebellar cortex in our study were described by other researchers as spongiform changes (SMD, 2015) which occurred due to loss of the cellular parts in the cerebellar cortex (Eluwa et al., 2013).

In this work, a significant increment in the mean area percentage of GFAP immunoreactivity in both molecular and granular layers was detected in the DM induced group (group IIla). GFAP is the main intermediate filament protein present in astrocytes and is considered a specific marker for them. The increase in the GFAP expression could be due to glial activation that occurred in association with the damage of the Purkinje cells secondary to DM. In this condition, the astrocytes enlarged in size and acquired thick processes and become strongly immuno-stained with the GFAP antibody (Der Perng et al., 2006). This finding is referred to as reactive gliosis and coincided with the findings of (El-Akabawy and El-Kholy, 2014) who attributed it to oxidative stress and changes in the blood glucose level and also considered it as an indicator of neuronal damage (Garman, 2011). In addition, other researchers illustrated that the increase in GFAP expression could be due to the formation of myeloarchitectonics and new synaptic connections (Sherif, 2017).

In the current research, the impact of DM on synaptogenesis in the cerebellar cortex was evaluated. Synaptophysin is a presynaptic protein associated with synaptogenesis and thus it is employed as a sensitive marker for the synaptic density (Jung et al., 2009). Our findings revealed that DM caused a significant increment in the immune-expression of synaptophysin in granular and molecular layers of the cerebellar cortex. These results came in accordance with (Sherif, 2017) who detected similar results in his study on diabetic rats. Another previous study by (Grillo et al., 2005) also reported that DM caused an increased expression of synaptophysin 
in the rat's hippocampus and attributed that increase to either the active synaptogenesis with formation of new synapses or the redistribution of proteins in the synapses that remained. These alterations were followed by changes in learning and memory indicating that these new synapses were usually abnormal.

Our electron microscopic results revealed further ultrastructural changes as irregularity and splitting of myelin sheaths in the molecular layer. This result came in agreement with (Ozdemir et al., 2016) who demonstrated separations and breaks of myelin sheaths in cerebellar cortex of diabetic rats. These alterations of the myelin sheaths were demonstrated to occur as a part of brain neuropathy that develops in different brain regions secondary to DM. Disarrangement of the myelin sheaths could be explained according to other researchers (Hernández-Fonseca et al., 2009; Hussein, 2015) to be due to inhibition of oligodendrocytes' function, decreased levels of myelin-associated glycoprotein and also formation of antibodies against myelin basic proteins. Dilatation of Golgi, rER, and perinuclear cisternae together with the vacuolations that were detected in our work was attributed to the effect of oxidative stress and lipid peroxidation induced by hyperglycemia developed in DM. This caused membranes' damage with subsequent increase in intracellular sodium and water content resulting in edema (Emanuel, 2001). Moreover, condensation and pyknosis of the granule cells in the granular layer were considered as a sign of apoptosis (Kumar et al., 2015).

In the current work, administration of oxymatrine in diabetic rats in group IIIb (diabetic-oxymatrine group) greatly preserved the cerebellar cortex structure and protected against the changes induced by DM. Oxymatrine was proved to have antioxidant properties evidenced by enhanced production of antioxidant enzymes such as catalase, GP-x and SOD (Wang et al., 2019). This was in agreement with the significant increment in the levels of GP-x and SOD that were detected in our study. The antioxidant effect of oxymatrine was also reported in various tissues, such as brain (Li et al., 2011), heart (Zhang et al., 2014), liver (Li et al., 2017) and kidney (Jiang et al., 2015). Moreover, in their study on rats' brain following intracerebral hemorrhage, Huang et al. (2020) illustrated that oxymatrine prevented brain's oxidative injury through reducing production of 12/15-LOX proteins which play an essential role in developing oxidative damage in the brain tissues. In addition, Huang et al. (Huang et al., 2020) reported that oxymatrine improved hippocampal histological structure and cognitive brain function in diabetic rats through suppression of the oxidative stress through reduced expression and activity of NOX2 and NOX4 which are considered main sources of ROS in brain tissue that play a role in neuronal damage. Other studies also demonstrated that oxymatrine increased activity of SOD and decreased synthesis and release of lipid peroxides and malondialdehyde, contributing to its antioxidant activities (Hong-li et al., 2008; Zhao et al., 2008). Thus, the protective effect of oxymatrine that was detected in group IIIb of the current study could be attributed to its antioxidant properties that minimized the impacts of the oxidative stress induced by DM and so exerted a neuroprotective effect on the cerebellar cortex of diabetic rats.

In addition to its antioxidant effects, accumulated data demonstrated that oxymatrine had anti-apoptotic activity on different models of diseases. In most of these models, oxymatrine protected the tissues and organs from damage by minimizing apoptosis through enhancing expression of anti-apoptotic genes and reducing the apoptotic ones (Dong et al., 2019; Fu et al., 2018). A previous study of (Zhang et al., 2017) revealed that oxymatrine prevented apoptosis of the hepatocytes and protected against acute liver failure in rats. Also, another study proved that oxymatrine protected the brain against hypoxic-ischemic brain injury by minimizing apoptosis in neonatal rats (Liu et al., 2020). Moreover, oxymatrine prevented neuronal cells from apoptosis that occurs in the rat brain after cerebral hemorrhage (Huang et al., 2012) and also inhibited apoptosis of neuronal cells in diabetic rats through reduction of both expression and activity of cleaved caspase-3 protein (Huang et al., 2020).

In addition, it was documented that oxymatrine had a regulatory role in DM and succeeded in reducing glucose blood level in diabetic rats (Huang et al., 2020). A previous work also showed that oxymatrine preserved the structure of the pancreatic islets, enhanced insulin production and sensitivity and reduced both hyperglycemia and hyperlipidemia in streptozotocin-induced diabetic rats (Zuo et al., 2019).

\section{Conclusion}

Diabetes mellitus induced histopathological alterations in the cerebellar cortex of rats. Oxymatrine has good impacts and has some neuroprotective effect on DM-induced cerebellar cortex changes. Thus, it is recommended for diabetic patients to administrate oxymatrine as an adjuvant therapy.

\section{Declarations}




\section{Conflict of interest}

The authors declare no conflicts of interest.

\section{Funding Sources}

This work was not funded by any grant sponsors or organizations.

\section{Author Contributions}

All authors contributed to the study conception and design. Material preparation, data collection and analysis were performed by [dr Amany Mohamed Shalaby], [dr Mona Tayssir Sadek], [dr Adel Mohamed Abo Regela] and [dr Mohamed Ali Alabiad. The first draft of the manuscript was written by [dr Amany Mohamed Shalaby] and all authors commented on previous versions of the manuscript. All authors read and approved the final manuscript.

\section{Ethical statement.}

All animal work was conducted under the guidelines for the use of animals in research established by the local ethical committee of the Faculty of Medicine, Tanta University, Egypt (Approval number: 34265/11/20).

\section{Data Availability}

Datasets are available in a public repository that assigns persistent identifiers to the datasets.

\section{References}

1. Allen, K.V., Frier, B.M., Strachan, M.W., 2004. The relationship between type 2 diabetes and cognitive dysfunction: longitudinal studies and their methodological limitations. European journal of pharmacology 490, 169-175.

2. Altinzo, E., Oner, Z., Elbe, H., Vardi, N., 2014. Neuro-protective effects of crocin on brain and cerebellum tissues in diabetic rats. African Journal of Traditional, Complementary and Alternative Medicines 11, 33-39.

3. Bak, D.H., Zhang, E., Yi, M.-H., Kim, D.-K., Lim, K., Kim, J.-J., Kim, D.W., 2015. High w3-polyunsaturated fatty acids in fat-1 mice prevent streptozotocin-induced Purkinje cell degeneration through BDNF-mediated autophagy. Scientific reports 5, 15465.

4. Brands, A.M., Kessels, R.P., de Haan, E.H., Kappelle, L.J., Biessels, G.J., 2004. Cerebral dysfunction in type 1 diabetes: effects of insulin, vascular risk factors and blood-glucose levels. European journal of pharmacology 490, 159-168.

5. Cui, L., Zhang, X., Yang, R., Wang, L., Liu, L., Li, M., Du, W., 2011. Neuroprotection and underlying mechanisms of oxymatrine in cerebral ischemia of rats. Neurological research 33, 319-324.

6. Dai, J.-P., Wang, Q.-W., Su, Y., Gu, L.-M., Deng, H.-X., Chen, X.-X., Li, W.-Z., Li, K.-S., 2018. Oxymatrine inhibits influenza A virus replication and inflammation via TLR4, p38 MAPK and NF-KB pathways. International journal of molecular sciences 19, 965.

7. Dawson-Saunders, B., Trapp, R., 2001. Section 5.6: proportions when the same group is measured twice. Basic \& clinical biostatistics: Lange medical book. 3rd ed. New York, Montreal: McGraw-Hill Book Co, 115-118.

8. DeBoer, T., Wewerka, S., Bauer, P.J., Georgieff, M.K., Nelson, C.A., 2005. Explicit memory performance in infants of diabetic mothers at 1 year of age. Developmental Medicine \& Child Neurology 47, 525-531.

9. Der Perng, M., Su, M., Wen, S.F., Li, R., Gibbon, T., Prescott, A.R., Brenner, M., Quinlan, R.A., 2006. The Alexander disease-causing glial fibrillary acidic protein mutant, R416W, accumulates into rosenthal fibers by a pathway that involves filament aggregation and the association of aB-crystallin and HSP27. The American Journal of Human Genetics 79, 197-213.

10. Ding, F., Li, Y., Hou, X., Zhang, R., Hu, S., Wang, Y., 2016. Oxymatrine inhibits microglia activation via HSP60-TLR4 signaling. Biomedical reports 5, 623-628.

11. Dong, P., Ji, X., Han, W., Han, H., 2019. Oxymatrine attenuates amyloid beta 42 (Aß1-42)-induced neurotoxicity in primary neuronal cells and memory impairment in rats. Canadian journal of physiology and pharmacology 97, 99-106.

12. Duarte, A.I., Moreira, P.I., Oliveira, C.R., 2012. Insulin in central nervous system: more than just a peripheral hormone. Journal of aging research 2012. 
13. El-Akabawy, G., El-Kholy, W., 2014. Neuroprotective effect of ginger in the brain of streptozotocin-induced diabetic rats. Annals of Anatomy-Anatomischer Anzeiger 196, 119-128.

14. El-Dien, S., El Gamal, D.A., Mubarak, H.A., Saleh, S.M., 2010. Effect of fluoride on rat cerebellar cortex: light and electron microscopic studies. Egypt J Histol 33, 245-246.

15. Eltahawy, N., El-Hady, A., Badawi, M., Hammad, A., 2017. Gamma amino butyric acid ameliorates jejunal oxidative damage in diabetic rats. Indian Journal of Pharmaceutical Education and Research 51, 588-596.

16. Eluwa, M., Inyangmme, I., Akpantah, A., Ekanem, T., Ekong, M., Asuquo, O., Nwakanma, A., 2013. A comparative study of the effect of diet and soda carbonated drinks on the histology of the cerebellum of adult female albino Wistar rats. African health sciences $13,541-545$.

17. Emanuel, R., 2001. Essential Pathlogy, 3rd ed. Lippincot Williams \& Wilkins, Baltimore, MD (USA), p. 1.

18. Fang, P., An, J., Tan, X., Zeng, L.-L., Shen, H., Qiu, S., Hu, D., 2017. Changes in the cerebellar and cerebro-cerebellar circuit in type 2 diabetes. Brain research bulletin 130, 95-100.

19. Fu, Y., Wu, H.q., Cui, H.I., Li, Y.y., Li, C.Z., 2018. Gastroprotective and anti-ulcer effects of oxymatrine against several gastric ulcer models in rats: Possible roles of antioxidant, antiinflammatory, and prosurvival mechanisms. Phytotherapy Research 32, $2047-$ 2058.

20. Funaya, N., Haginaka, J., 2012. Matrine-and oxymatrine-imprinted monodisperse polymers prepared by precipitation polymerization and their applications for the selective extraction of matrine-type alkaloids from Sophora flavescens Aiton. Journal of Chromatography A 1248, 18-23.

21. Gamble, M, 2008. The hematoxylins and eosin., In: Theory and Practice of Histological Techniques, 6th ed. Churchill Livingstone, Elsevier: Philadelphia, PA, pp. 121-134.

22. Garman, R.H., 2011. Histology of the central nervous system. Toxicologic pathology 39, 22-35.

23. Grillo, C., Piroli, G., Wood, G., Reznikov, L., McEwen, B., Reagan, L., 2005. Immunocytochemical analysis of synaptic proteins provides new insights into diabetes-mediated plasticity in the rat hippocampus. Neuroscience 136, 477-486.

24. Hami, J., Vafaei-Nezhad, S., Ivar, G., Sadeghi, A., Ghaemi, K., Mostafavizadeh, M., Hosseini, M., 2016. Altered expression and localization of synaptophysin in developing cerebellar cortex of neonatal rats due to maternal diabetes mellitus. Metabolic brain disease 31, 1369-1380.

25. Hashish, H., 2015. Alteration of glial fibrillary acidic protein immunoreactivity in astrocytes of the cerebellum of diabetic rats and potential effect of insulin and ginger. Anat Physiol 5, 2161-0940.1000167.

26. Hernández-Fonseca, J.P., Rincón, J., Pedreañez, A., Viera, N., Arcaya, J.L., Carrizo, E., Mosquera, J., 2009. Structural and ultrastructural analysis of cerebral cortex, cerebellum, and hypothalamus from diabetic rats. Experimental Diabetes Research 2009.

27. Hong-li, S., Lei, L., Lei, S., Dan, Z., De-li, D., Guo-fen, Q., Yan, L., Wen-feng, C., Bao-feng, Y., 2008. Cardioprotective effects and underlying mechanisms of oxymatrine against Ischemic myocardial injuries of rats. Phytotherapy Research 22, 985-989.

28. Huang, L., Wang, C., Ge, R., Ni, H., Zhao, S., 2017. Ischemia deteriorates spike encoding at cortical GABAergic neurons and cerebellar Purkinje cells by increasing the intracellular Ca2+. Brain Research Bulletin 131, 55-61.

29. Huang, M., Hu, Y.-Y., Dong, X.-Q., Xu, Q.-P., Yu, W.-H., Zhang, Z.-Y., 2012. The protective role of oxymatrine on neuronal cell apoptosis in the hemorrhagic rat brain. Journal of ethnopharmacology 143, 228-235.

30. Huang, Y., Li, X., Zhang, X., Tang, J., 2020. Oxymatrine Ameliorates Memory Impairment in Diabetic Rats by Regulating Oxidative Stress and Apoptosis: Involvement of NOX2/NOX4. Oxidative medicine and cellular longevity 2020.

31. Hussein, O.A., 2015. Effect of genistein on the cerebellar cortex of adult male albino rats with streptozotocin-induced diabetes mellitus: a histological and immunohistochemical study. The Egyptian Journal of Histology 38, 778-792.

32. Jiang, G., Liu, X., Wang, M., Chen, H., Chen, Z., Qiu, T., 2015. Oxymatrine ameliorates renal ischemia-reperfusion injury from oxidative stress through Nrf2/HO-1 pathway. Acta Cirurgica Brasileira 30, 422-429.

33. Jung, S.H., Lee, S.-T., Chu, K., Park, J.-E., Lee, S.-U., Han, T.-R., Kim, M., 2009. Cell proliferation and synaptogenesis in the cerebellum after focal cerebral ischemia. Brain research 1284, 180-190.

34. Kleinridders, A., Ferris, H.A., Cai, W., Kahn, C.R., 2014. Insulin action in brain regulates systemic metabolism and brain function. Diabetes 63, 2232-2243. 
35. Kumar, V., Abbas, A.K., Fausto, N., Aster, J.C., 2015. Robbins and Cotran pathologic basis of disease, 9th ed. Elsevier

36. , Philadelphia, USA.

37. Li, L., Liu, Q., Fan, L., Xiao, W., Zhao, L., Wang, Y., Ye, W., Lan, F., Jia, B., Feng, H., 2017. Protective effects of oxymatrine against arsenic trioxide-induced liver injury. Oncotarget $8,12792$.

38. Li, M., Zhang, X., Cui, L., Yang, R., Wang, L., Liu, L., Du, W., 2011. The neuroprotection of oxymatrine in cerebral ischemia/reperfusion is related to nuclear factor erythroid 2-related factor 2 (nrf2)-mediated antioxidant response: role of nrf2 and hemeoxygenase-1 expression. Biological and Pharmaceutical Bulletin 34, 595-601.

39. Liu, G., Zhang, C., Yin, J., Li, X., Cheng, F., Li, Y., Yang, H., Uéda, K., Chan, P., Yu, S., 2009. a-Synuclein is differentially expressed in mitochondria from different rat brain regions and dose-dependently down-regulates complex I activity. Neuroscience letters 454 , 187-192.

40. Liu, Y., Wang, H., Liu, N., Du, J., Lan, X., Qi, X., Zhuang, C., Sun, T., Li, Y., Yu, J., 2020. Oxymatrine protects neonatal rat against hypoxic-ischemic brain damage via PI3K/Akt/GSK3 $\beta$ pathway. Life sciences 254, 116444.

41. Marklund, S., Marklund, G., 1974. Involvement of the superoxide anion radical in the autoxidation of pyrogallol and a convenient assay for superoxide dismutase. European journal of biochemistry 47, 469-474.

42. Mohammadi, J., Saadipour, K., Delaviz, H., Mohammadi, B., 2011. Anti-diabetic effects of an alcoholic extract of Juglans regia in an animal model. Turkish Journal of Medical Sciences 41, 685-691.

43. Nagayach, A., Patro, N., Patro, I., 2014. Astrocytic and microglial response in experimentally induced diabetic rat brain. Metabolic brain disease 29, 747-761.

44. Ozdemir, N.G., Akbas, F., Kotil, T., Yılmaz, A., 2016. Analysis of diabetes related cerebellar changes in streptozotocin-induced diabetic rats. Turkish journal of medical sciences 46, 1579-1592.

45. Ozougwu, J., Obimba, K., Belonwu, C., Unakalamba, C., 2013. The pathogenesis and pathophysiology of type 1 and type 2 diabetes mellitus. Journal of physiology and pathophysiology 4, 46-57.

46. Paglia, D.E., Valentine, W.N., 1967. Studies on the quantitative and qualitative characterization of erythrocyte glutathione peroxidase. The Journal of laboratory and clinical medicine 70, 158-169.

47. Patel, P., Macerollo, A., 2010. Diabetes mellitus: diagnosis and screening. American family physician 81, 863-870.

48. Razi, E.M., Ghafari, S., Golalipour, M.J., 2015. Effect of gestational diabetes on purkinje and granule cells distribution of the rat cerebellum in 21 and 28 days of postnatal life. Basic and clinical neuroscience 6, 6.

49. Shalaby, A.M., Bahey, N.G., 2018. Reversal of the hepatic damage induced by the supraphysiological dose of nandrolone decanoate after its withdrawal in the adult male rat. Tissue and Cell 53, 44-52.

50. Sherif, R.N., 2017. Effect of cerebrolysin on the cerebellum of diabetic rats: An imunohistochemical study. Tissue and Cell 49, 726-733.

51. Shi, L., Shi, L., Zhang, H., Hu, Z., Wang, C., Zhang, D., Song, G., 2013. Oxymatrine ameliorates non-alcoholic fatty liver disease in rats through peroxisome proliferator-activated receptor- $a$ activation. Molecular medicine reports 8, 439-445.

52. SMD, H., 2015. Neurohistological effects of lead on pons of adult albimo rat. GJRA 4, 452-453.

53. Solmaz, V., Köse Özlece, H., Eroglu, H.A., Aktuğ, H., Erbaş, O., Taşkıran, D., 2017. Accumulation of a-Synuclein in cerebellar Purkinje cells of diabetic rats and its potential relationship with inflammation and oxidative stress markers. Neurology research international 2017.

54. Tedesco, A.M., Chiricozzi, F.R., Clausi, S., Lupo, M., Molinari, M., Leggio, M.G., 2011. The cerebellar cognitive profile. Brain 134, 3672-3686.

55. Uchiyama, M., Mihara, M., 1978. Determination of malonaldehyde precursor in tissues by thiobarbituric acid test. Analytical biochemistry 86, 271-278.

56. Wang, Y.-P., Zhao, W., Xue, R., Zhou, Z.-X., Liu, F., Han, Y.-X., Ren, G., Peng, Z.-G., Cen, S., Chen, H.-S., 2011. Oxymatrine inhibits hepatitis $B$ infection with an advantage of overcoming drug-resistance. Antiviral Research 89, 227-231.

57. Wang, Y., Shou, Z., Fan, H., Xu, M., Chen, Q., Tang, Q., Liu, X., Wu, H., Zhang, M., Yu, T., 2019. Protective effects of oxymatrine against DSS-induced acute intestinal inflammation in mice via blocking the RhoA/ROCK signaling pathway. Bioscience reports 39. 
58. Woods, A., Stirling, J., 2008. Electron microscope, In: Theory and Practice of Histological Techniques. Churchill Livingstone/Elsevier, Philadelphia, PA, p. 600.

59. Wu, C., Huang, W., Guo, Y., Xia, P., Sun, X., Pan, X., Hu, W., 2015. Oxymatrine inhibits the proliferation of prostate cancer cells in vitro and in vivo. Molecular medicine reports 11, 4129-4134.

60. Xu, Y.-Q., Jin, S.-J., Liu, N., Li, Y.-X., Zheng, J., Ma, L., Du, J., Zhou, R., Zhao, C.-J., Niu, Y., 2014. Aloperine attenuated neuropathic pain induced by chronic constriction injury via anti-oxidation activity and suppression of the nuclear factor kappa B pathway. Biochemical and biophysical research communications 451, 568-573.

61. Zeng, X.-Y., Zhou, X., Xu, J., Chan, S.M., Xue, C.L., Molero, J.C., Ye, J.-M., 2012. Screening for the efficacy on lipid accumulation in 3T3-L1 cells is an effective tool for the identification of new anti-diabetic compounds. Biochemical pharmacology 84, 830-837.

62. Zhang, W., Zhang, J., Kang, Y., Liu, J., Wang, X., Xu, Q., Wang, Y., Xu, X., Dai, G., 2014. Cardioprotective effects of oxymatrine on isoproterenol-induced heart failure via regulation of DDAH/ADMA metabolism pathway in rats. European journal of pharmacology 745, 29-35.

63. Zhang, X., Jiang, W., Zhou, A.-L., Zhao, M., Jiang, D.-R., 2017. Inhibitory effect of oxymatrine on hepatocyte apoptosis via TLR4/PI3K/Akt/GSK-3 $\beta$ signaling pathway. World Journal of Gastroenterology 23, 3839.

64. Zhao, B., Pan, B.-S., Shen, S.-W., Sun, X., Hou, Z.-Z., Yan, R., Sun, F.-Y., 2013. Diabetes-induced central neuritic dystrophy and cognitive deficits are associated with the formation of oligomeric reticulon-3 via oxidative stress. Journal of Biological Chemistry 288, 15590-15599.

65. Zhao, J., Yu, S., Tong, L., Zhang, F., Jiang, X., Pan, S., Jiang, H., Sun, X., 2008. Oxymatrine attenuates intestinal ischemia/reperfusion injury in rats. Surgery today 38, 931-937.

66. Zhou, R., Xu, Q., Xu, Y., Xiong, A., Wang, Y., Ma, P., 2016. Oxymatrine attenuated isoproterenol-induced heart failure in rats via regulation of COX-2/PGI2 pathway. Biomedicine \& Pharmacotherapy 84, 1359-1366.

67. Zuo, M.L., Wang, A.P., Tian, Y., Mao, L., Song, G.L., Yang, Z.B., 2019. Oxymatrine ameliorates insulin resistance in rats with type 2 diabetes by regulating the expression of KSRP, PETN, and AKT in the liver. Journal of cellular biochemistry 120, 16185-16194.

\section{Tables}

Table 1: Biochemical and statistical analysis of different studied groups. 


\begin{tabular}{|c|c|c|c|c|c|c|c|c|c|c|c|c|c|c|}
\hline & \multicolumn{3}{|c|}{$\begin{array}{l}\text { Control group } \\
\text { (Group I) }\end{array}$} & \multicolumn{3}{|c|}{$\begin{array}{l}\text { Oxymatrine group } \\
\text { (Group II) }\end{array}$} & \multicolumn{3}{|c|}{$\begin{array}{l}\text { Induced diabetic } \\
\text { group (Subgroup } \\
\text { Illa) }\end{array}$} & \multicolumn{3}{|c|}{$\begin{array}{l}\text { Induced diabetic- } \\
\text { oxymatrine group } \\
\text { (Subgroup Illb) }\end{array}$} & \\
\hline & Mean & \pm & SD & Mean & \pm & SD & Mean & \pm & SD & Mean & \pm & SD & $F$ & P-value \\
\hline $\begin{array}{l}\text { Blood } \\
\text { glucose } \\
\text { level } \\
\text { (mg/dl) }\end{array}$ & 104.43 & \pm & 9.59 & 97.24 & \pm & 13.56 & 323.88 & \pm & 20.68 & 265.98 & \pm & 62.84 & 78.981 & $<0.001^{\star}$ \\
\hline $\begin{array}{l}\text { MDA } \\
\text { nmol/g } \\
\text { tissue } \\
\text { protein }\end{array}$ & 70.09 & \pm & 2.29 & 70.26 & \pm & 3.14 & 91.59 & \pm & 4.88 & 70.53 & \pm & 3.60 & 61.213 & $<0.001^{\star}$ \\
\hline $\begin{array}{l}\text { GP-x } \\
\text { U/mg } \\
\text { protein }\end{array}$ & 0.68 & \pm & 0.03 & 0.69 & \pm & 0.07 & 0.41 & \pm & 0.03 & 0.66 & \pm & 0.07 & 43.934 & $<0.001^{\star}$ \\
\hline $\begin{array}{l}\text { SOD U/g } \\
\text { tissue } \\
\text { protein }\end{array}$ & 39.61 & \pm & 3.01 & 39.46 & \pm & 2.25 & 25.19 & \pm & 3.24 & 36.79 & \pm & 5.35 & 24.611 & $<0.001^{*}$ \\
\hline \multicolumn{15}{|c|}{ TUKEY'S Test } \\
\hline & I\&II & \multicolumn{2}{|l|}{ I\&IIla } & \multicolumn{3}{|c|}{ I\&ll|b } & \multicolumn{2}{|c|}{ II\&\|lla } & \multicolumn{2}{|c|}{ \|\&\|llb } & & & \multicolumn{2}{|l|}{ Illa\&lllb } \\
\hline $\begin{array}{l}\text { Blood } \\
\text { glucose } \\
\text { level } \\
\text { (mg/dl) }\end{array}$ & 0.979 & $<0.001 *$ & & \multicolumn{3}{|c|}{$<0.001^{\star}$} & \multicolumn{2}{|c|}{$<0.001 *$} & \multicolumn{2}{|c|}{$<0.001 *$} & & & \multicolumn{2}{|l|}{$0.020^{*}$} \\
\hline $\begin{array}{l}\text { MDA } \\
\text { nmol/g } \\
\text { tissue } \\
\text { protein }\end{array}$ & 1.000 & \multicolumn{2}{|l|}{$<0.001^{\star}$} & \multicolumn{3}{|c|}{0.996} & \multicolumn{2}{|c|}{$<0.001 *$} & \multicolumn{2}{|c|}{0.999} & & & \multicolumn{2}{|l|}{$<0.001^{\star}$} \\
\hline $\begin{array}{l}\text { GPX } \\
\text { U/mg } \\
\text { protein }\end{array}$ & 0.945 & \multicolumn{2}{|l|}{$<0.001 *$} & \multicolumn{3}{|c|}{0.930} & \multicolumn{2}{|c|}{$<0.001 *$} & \multicolumn{2}{|c|}{0.660} & & & \multicolumn{2}{|l|}{$<0.001 *$} \\
\hline $\begin{array}{l}\text { SOD U/g f } \\
\text { tissue } \\
\text { protein }\end{array}$ & 1.000 & \multicolumn{2}{|l|}{$<0.001 *$} & \multicolumn{3}{|c|}{0.483} & \multicolumn{2}{|c|}{$<0.001$ * } & \multicolumn{2}{|c|}{0.528} & & & \multicolumn{2}{|l|}{$<0.001 *$} \\
\hline
\end{tabular}

* indicates Significance

Table 2: Morphometrical and statistical analysis of different studied groups. 


\begin{tabular}{|c|c|c|c|c|c|c|c|c|c|c|c|c|c|c|}
\hline & \multicolumn{3}{|c|}{$\begin{array}{l}\text { Control group } \\
\text { (Group I) }\end{array}$} & \multicolumn{3}{|c|}{$\begin{array}{l}\text { Oxymatrine group } \\
\text { (Group II) }\end{array}$} & \multicolumn{3}{|c|}{$\begin{array}{l}\text { Induced diabetic } \\
\text { group (Subgroup } \\
\text { Illa) }\end{array}$} & \multicolumn{3}{|c|}{$\begin{array}{l}\text { Induced diabetic- } \\
\text { oxymatrine group } \\
\text { (Subgroup Illb) }\end{array}$} & \multicolumn{2}{|l|}{ ANOVA } \\
\hline & Mean & \pm & SD & Mean & \pm & SD & Mean & \pm & SD & Mean & \pm & SD & $F$ & P-value \\
\hline $\begin{array}{l}\text { Mean number } \\
\text { of Purkinje } \\
\text { cells } / \mathrm{mm}\end{array}$ & 21.12 & \pm & 1.51 & 20.64 & \pm & 1.09 & 9.05 & \pm & 1.53 & 19.50 & \pm & 1.49 & 163.375 & $<0.001^{*}$ \\
\hline $\begin{array}{l}\text { Mean area } \\
\text { percentage of } \\
\text { GFAP }\end{array}$ & 9.70 & \pm & 0.79 & 9.68 & \pm & 0.66 & 30.02 & \pm & 0.62 & 10.15 & \pm & 0.43 & 2508.325 & $<0.001$ * \\
\hline $\begin{array}{l}\text { Mean optical } \\
\text { density of } \\
\text { GFAP }\end{array}$ & 11.44 & \pm & 1.57 & 11.35 & \pm & 1.52 & 27.20 & \pm & 3.51 & 8.96 & \pm & 1.27 & 150.325 & $<0.001^{*}$ \\
\hline $\begin{array}{l}\text { Mean optical } \\
\text { density of } \\
\text { synaptophysin }\end{array}$ & 12.53 & \pm & 0.80 & 13.11 & \pm & 0.79 & 33.85 & \pm & 0.73 & 15.43 & \pm & 0.58 & 1940.495 & $<0.001^{*}$ \\
\hline \multicolumn{15}{|l|}{ TUKEY'S Test } \\
\hline & I\&ll & \multicolumn{2}{|l|}{ I\&Illa } & \multicolumn{3}{|c|}{$|\&||| b$} & \multicolumn{2}{|c|}{ II\&llla } & \multicolumn{2}{|c|}{ II\&IIlb } & & & \multicolumn{2}{|c|}{ Illa\&IIlb } \\
\hline $\begin{array}{l}\text { Mean number } \\
\text { of Purkinje } \\
\text { cells } / \mathrm{mm}\end{array}$ & 0.873 & \multicolumn{2}{|l|}{$<0.001^{*}$} & \multicolumn{3}{|c|}{0.067} & \multicolumn{2}{|c|}{$<0.001^{\star}$} & \multicolumn{2}{|c|}{0.288} & & & \multicolumn{2}{|c|}{$<0.001^{\star}$} \\
\hline $\begin{array}{l}\text { Mean area } \\
\text { percentage of } \\
\text { GFAP }\end{array}$ & 1.000 & \multicolumn{2}{|l|}{$<0.001 *$} & \multicolumn{3}{|c|}{0.409} & \multicolumn{2}{|c|}{$<0.001 *$} & \multicolumn{2}{|c|}{0.363} & & & \multicolumn{2}{|c|}{$<0.001^{\star}$} \\
\hline $\begin{array}{l}\text { Mean optical } \\
\text { density of } \\
\text { GFAP }\end{array}$ & 1.000 & \multicolumn{2}{|l|}{$<0.001^{\star}$} & \multicolumn{3}{|c|}{0.067} & \multicolumn{2}{|c|}{$<0.001^{\star}$} & \multicolumn{2}{|c|}{0.082} & & & \multicolumn{2}{|c|}{$<0.001^{\star}$} \\
\hline $\begin{array}{l}\text { Mean optical } \\
\text { density of } \\
\text { synaptophysin }\end{array}$ & 0.300 & \multicolumn{2}{|l|}{$<0.001^{\star}$} & \multicolumn{3}{|c|}{$<0.001^{\star}$} & \multicolumn{2}{|c|}{$<0.001^{\star}$} & \multicolumn{2}{|c|}{$<0.001^{\star}$} & & & \multicolumn{2}{|c|}{$<0.001^{\star}$} \\
\hline
\end{tabular}

* indicates Significance

\section{Figures}




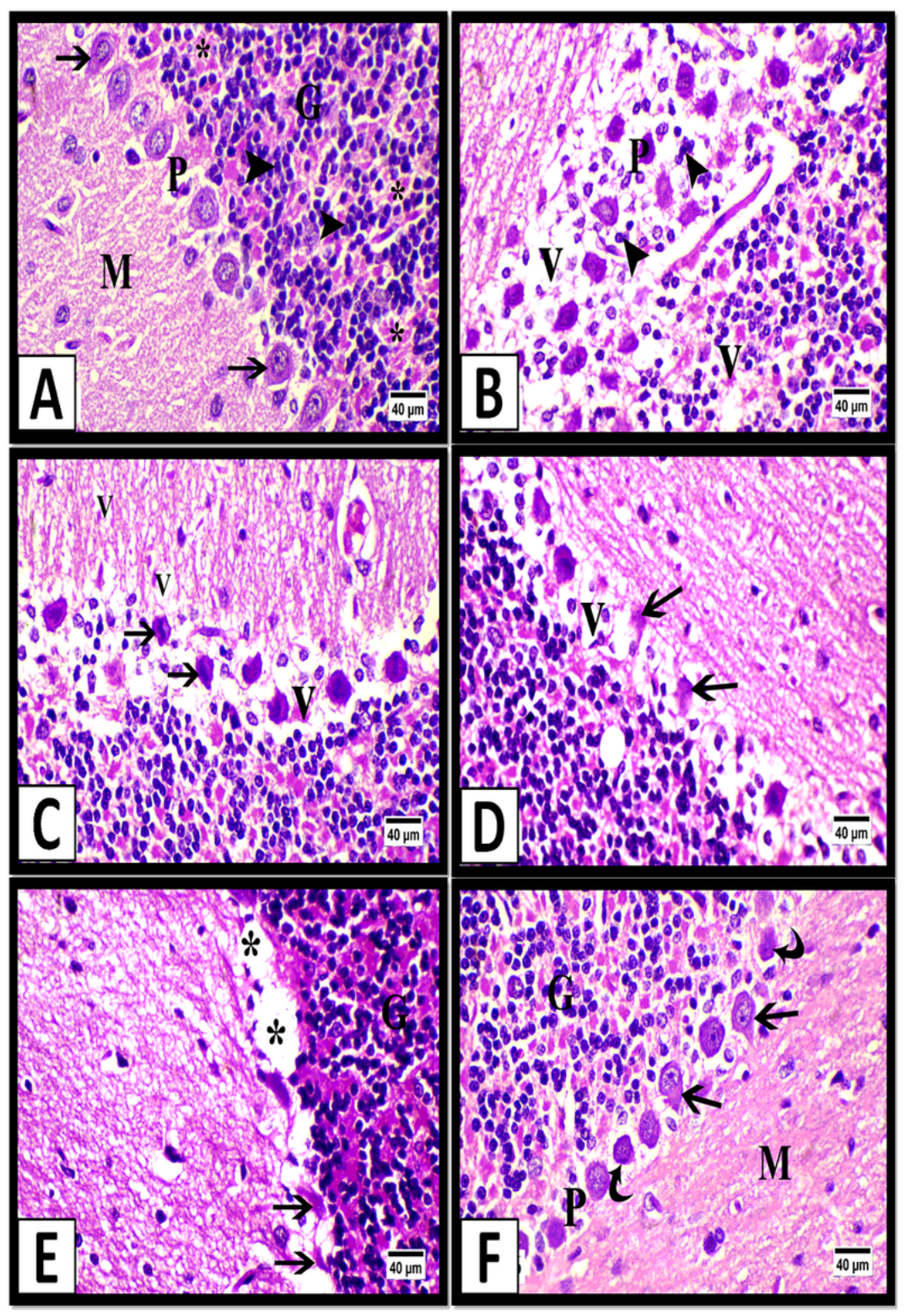

\section{Figure 1}

Cerebellar cortex sections of the control group revealing; [A] The cerebellar cortex displaying its three layers; the molecular layer (M), the Purkinje cell layer $(P)$ that consists of one row of large pear-shaped cells with vesicular nuclei and prominent nucleoli (arrows) and the granular cell layer $(\mathrm{G})$ that demonstrates densely packed rounded cells with darkly stained nuclei (arrowheads) with cerebellar islands (asterisks) in-between. Cerebellar cortex sections of the induced diabetic group (subgroup IIla) displayed; [B] Arrangement of Purkinje cells in many layers $(P)$ with many neuroglial cells in-between (arrowheads). Vacuolation $(V)$ is observed in the Purkinje and granular cell layers . [C] Irregular Purkinje cells with shrunken deeply stained nuclei (arrows). Notice, vacuolation (V) of the Purkinje and molecular layers (V). [D] Purkinje cells with eosinophilic homogenization of their cytoplasm and faint nuclei (arrows). Notice, vacuolation (V) of Purkinje cell layer (V). [E] Focal disappearance of Purkinje cells (asterisks) and presence of cell remnants (arrows). Notice, darkly stained cells in the granular layer (G). The induced diabetic-oxymatrine group (subgroup IIIb) revealing; [F] The cerebellar cortex appears normal as regards the molecular $(M)$, Purkinje cell $(P)$ and the granular $(G)$ layers. Few shrunken darkly stained Purkinje cells (curved arrow) are observed. (H\&E $\times 400$, scale bar $=40 \mu \mathrm{m})$. 

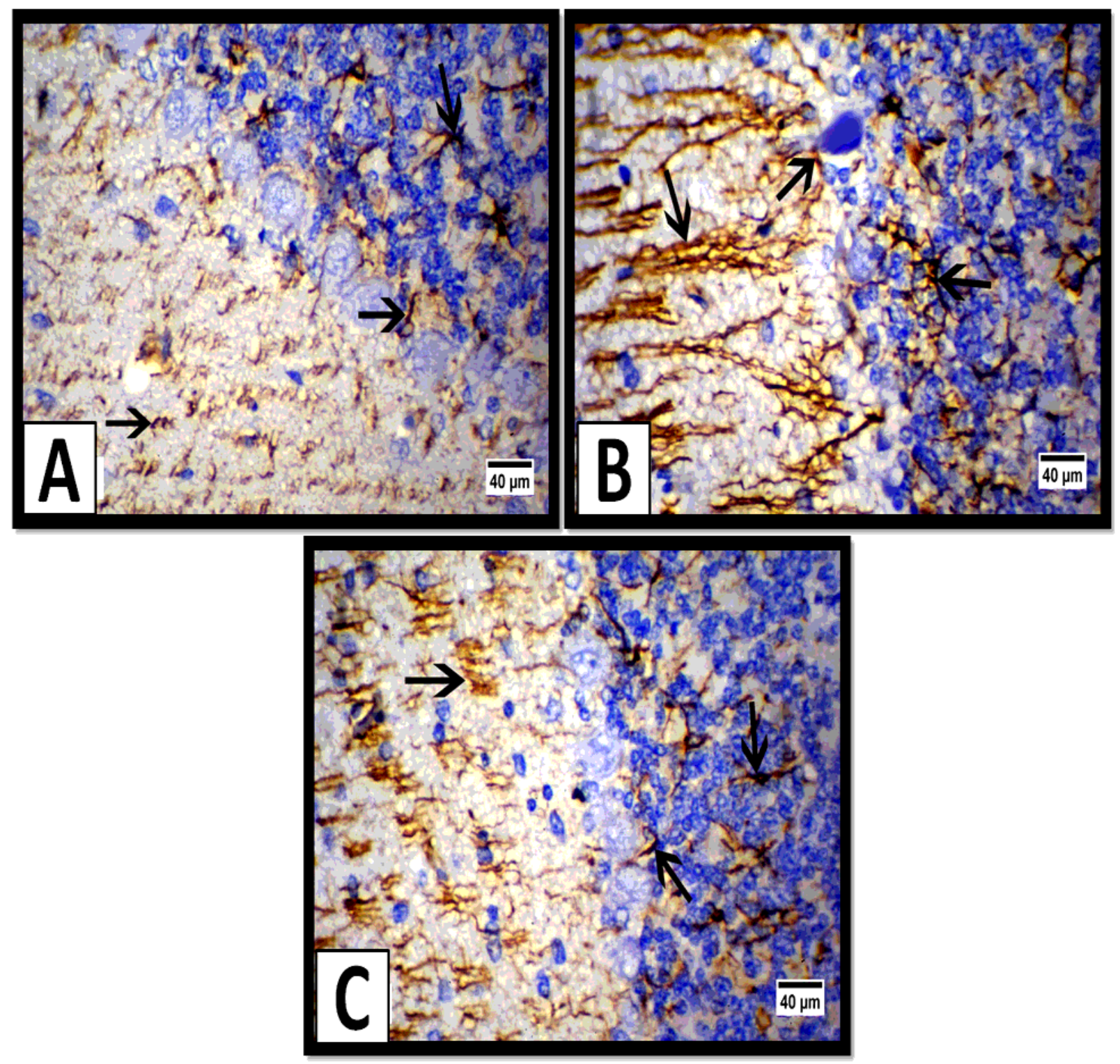

Figure 2

GFAP-immunostained cerebellar cortex sections of the control group showing; [A] Mild GFAP expression in the astrocytes (arrows) of all cortical layers. The induced diabetic group (subgroup IIIa) displayed; [B] Intense GFAP expression in the astrocytes (arrows) of all cortical layers. The induced diabetic-oxymatrine group (subgroup IIIb) revealing; [C] Moderate GFAP expression in the astrocytes (arrows) of all cortical layers. (GFAP immunostaining $\times 400$, scale bar $=40 \mu \mathrm{m}$ ). 

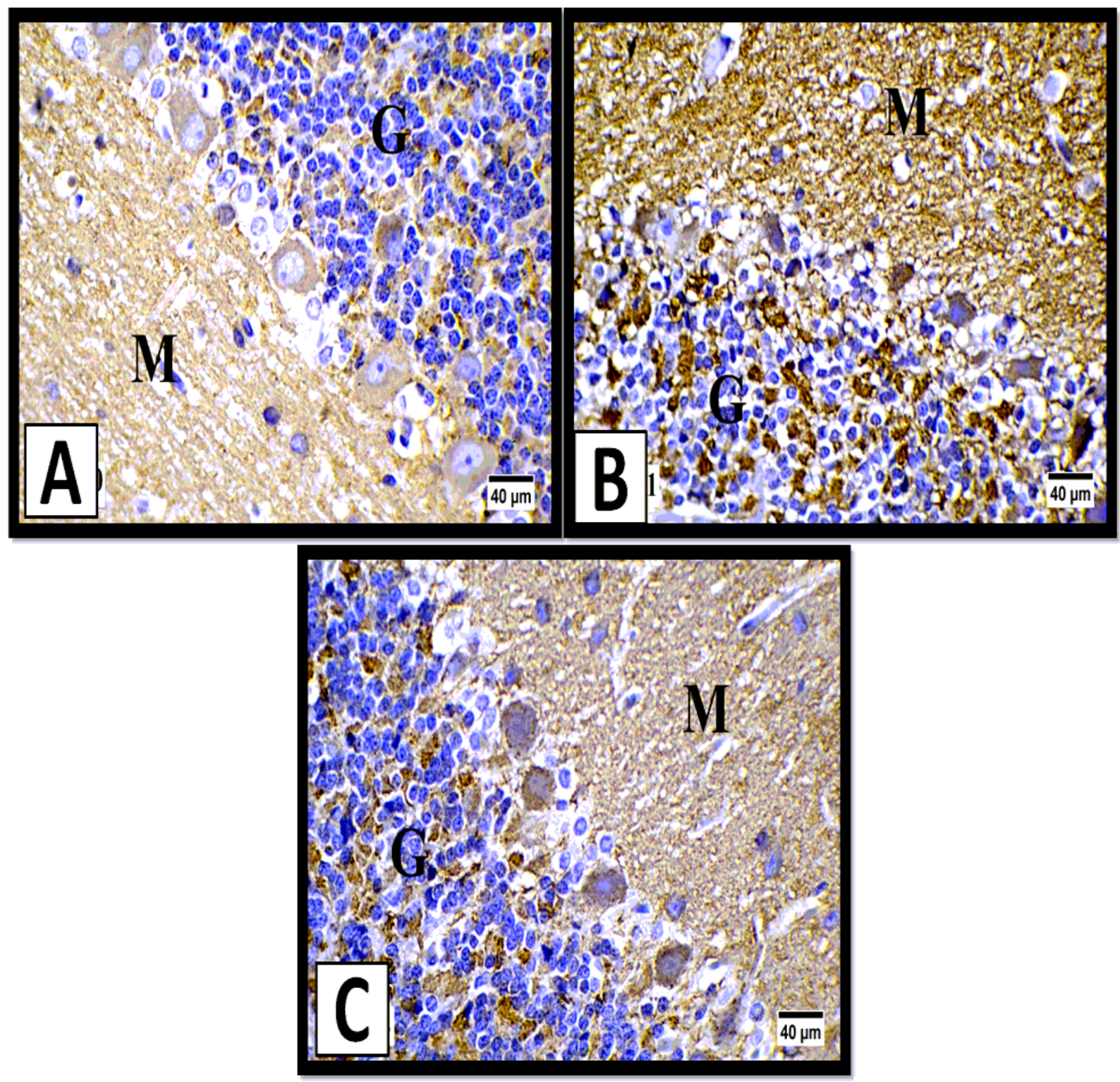

Figure 3

Synaptophysin -immunostained cerebellar cortex sections of the control group showing; [A] Weak synaptophysin expression in the molecular and granular layers. The induced diabetic group (subgroup Illa) displayed; [B] Strong synaptophysin expression in the molecular and granular layers. The induced diabetic-oxymatrine group (subgroup IIIb) revealing; [C] Moderate synaptophysin expression in the molecular and granular layers. (Synaptophysin immunostaining $\times 400$, scale bar $=40 \mu \mathrm{m}$ ). 

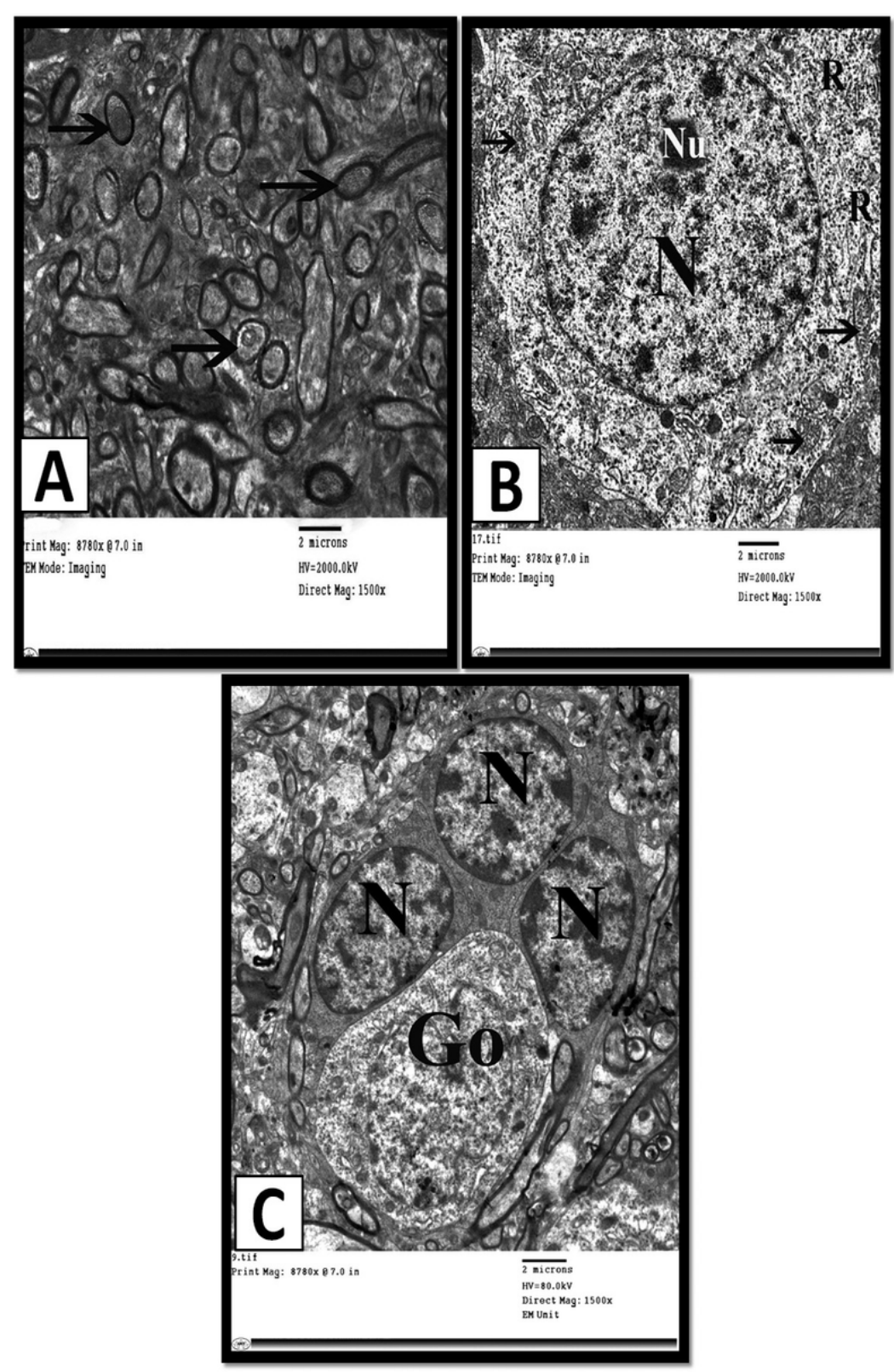

\section{Figure 4}

Transmission electron Microscopy of the control group demonstrating; [A] The molecular layer showing regular arrangement of myelin sheaths (arrows). [B] A perikaryon of normal Purkinje cell containing large euchromatic nucleus $(\mathrm{N})$ with prominent nucleolus $(\mathrm{Nu})$, mitochondria (arrows) and rER (R). [C] Granule cells having heterochromatic nuclei $(\mathrm{N})$ and thin rim of cytoplasm. Notice, a Golgi cell (Go). $($ TEM $\times 1500$, scale bar $=2 \mu \mathrm{m})$. 


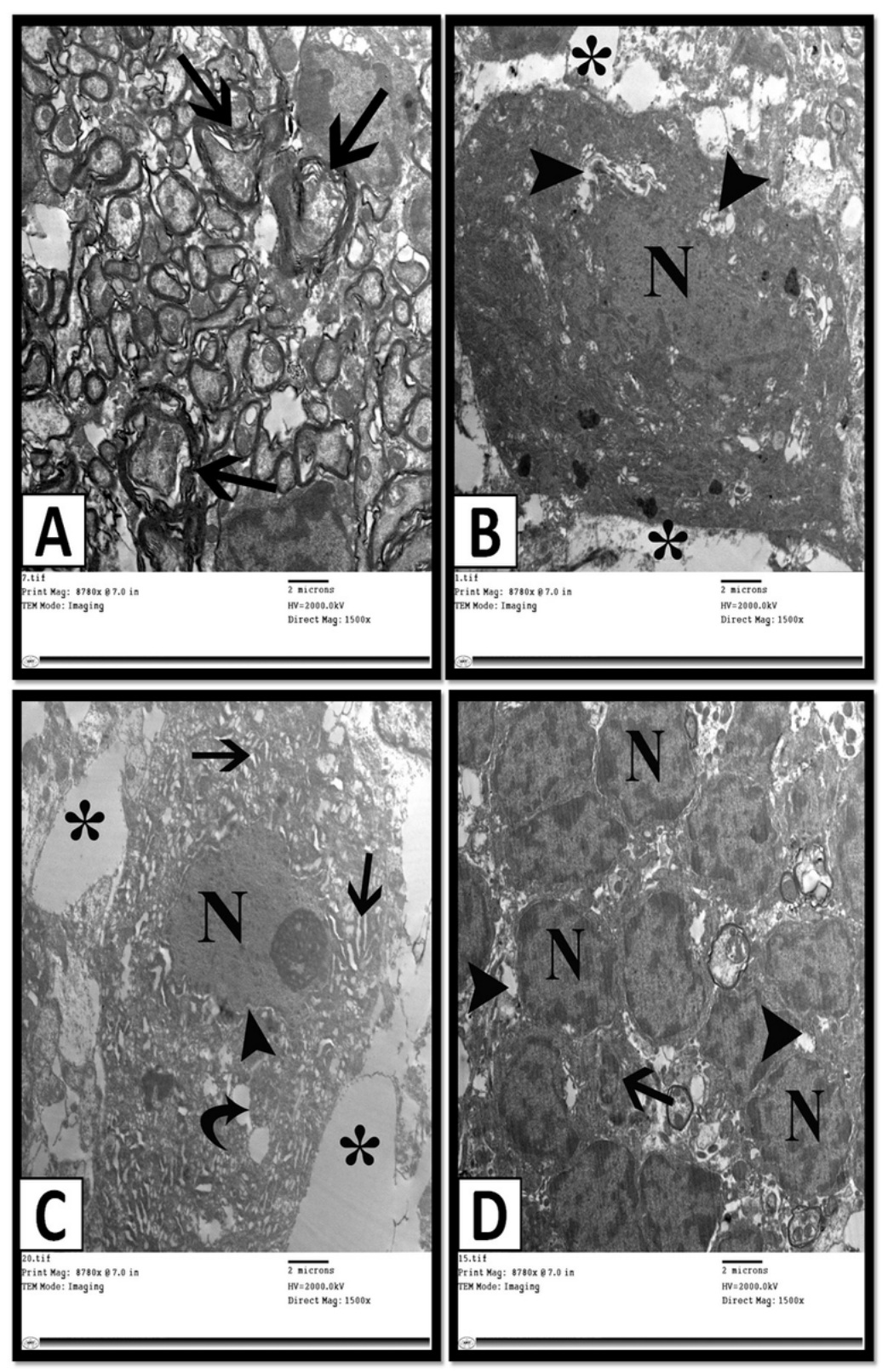

\section{Figure 5}

Transmission electron Microscopy of the induced diabetic group (subgroup Illa) demonstrating; [A] The molecular layer showing irregularity and splitting of the myelin sheaths (arrows). [B] A shrunken dark Purkinje cell with ill-defined nucleus (N) and dilated multiple Golgi saccules (arrowheads). Notice, vacuolated neuropil (asterisks). [C] A Purkinje cell having an irregular nucleus (N) with dilated perinuclear cisternae (arrowhead), dilated rER (arrows) and vacuolated cytoplasm (curved arrow). Notice vacuolated neuropil (asterisks). [D] Dark granule cells with irregular nuclear outlines $(\mathrm{N})$ and vacuolated cytoplasm (arrowheads). Notice, a granule cell with pyknotic nucleus (arrow). $($ TEM $\times 1500$, scale bar $=2 \mu \mathrm{m})$. 


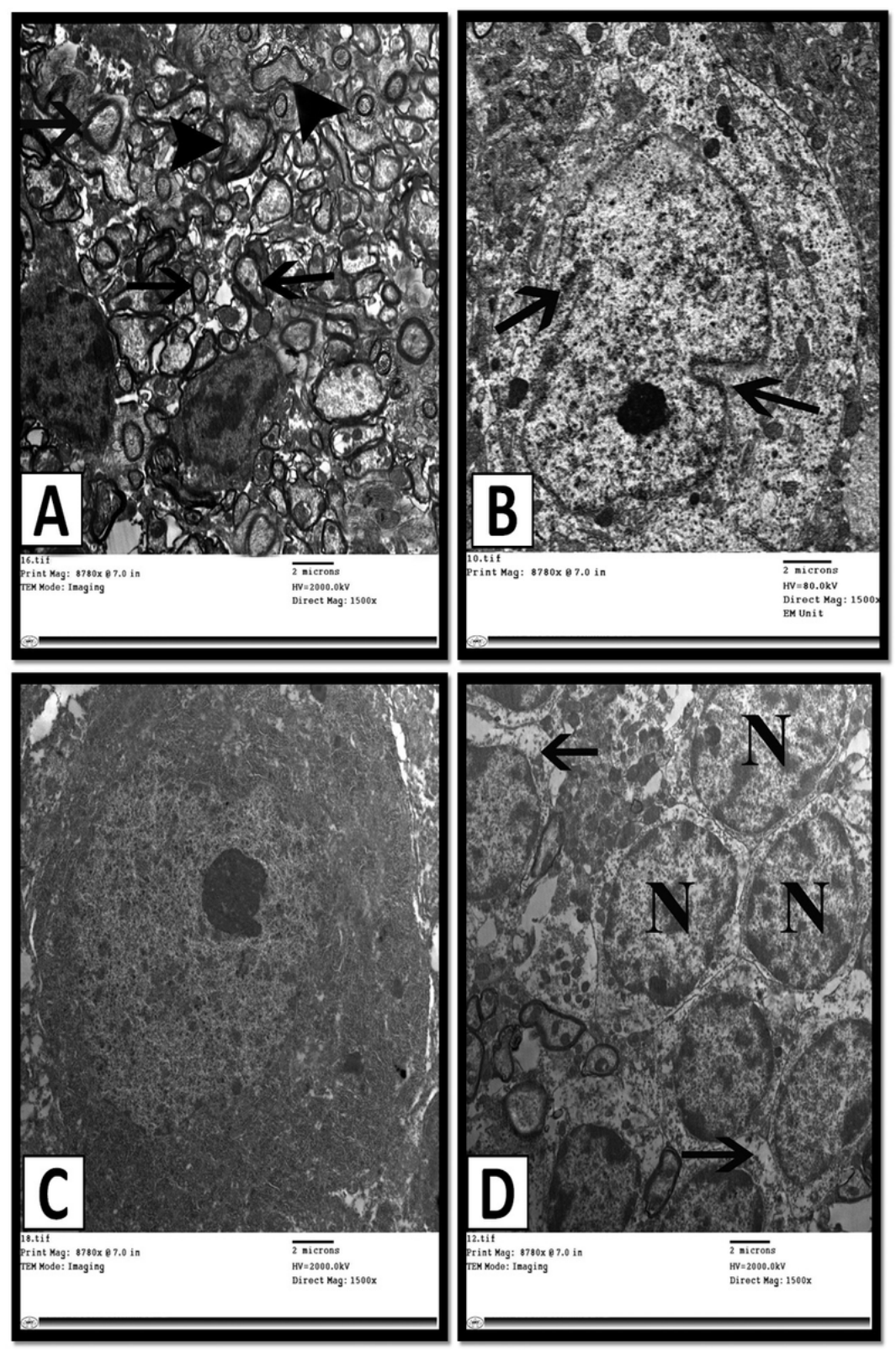

Figure 6

Transmission electron Microscopy of the induced diabetic-oxymatrine group (subgroup IIIb) revealing; [A]The molecular layer shows regular arrangement of the myelin sheaths of most of the nerve fibers (arrows). Few nerve fibers show irregularity of the myelin sheaths (arrowheads). [B] An apparently normal Purkinje cell with indentation of its nuclear envelope (arrows). [C] An apparently normal Purkinje cell with dark cytoplasm. [D] An apparently normal granule cells with heterochromatic nuclei (N). Some cells show rarefaction of their cytoplasm (arrows). (TEM $\times 1500$, scale bar $=2 \mu \mathrm{m})$. 